distinct types further and further every year. It is now established that there was an excessively sudden appearance of vast numbers of forms in the Cambrian, or perhaps earlier, as claimed by Professor Marcou and others.

We have applied this specific statement as a generalization to the history of smaller groups of fossils in several branches of the animal kingdom and in many formations, and have found that the sudden appearance of the smaller groups occurs according to the same law.

There is an obvious plasticity in the animals which first make their appearance in any unoccupied field, or at the beginning of any new formation, which reminds one of the plastic nature of the most generalized type of Metazoa, the existing Porifera. The generalized types, which always occur first in time, exhibit like sponges exceptional capacity for adaptation to the most varied requirements of the surroundings and all of the conditions of the new period or habitat by the rapid development of numbers of suitable and more highly specialized forms, species and genera.

The whole picture as presented by morphology, embryology, and palæontology favours the hypothesis we have previously advanced in other papers, namely that the early geologic history of animal life, like the early stages of development in the embryo, was a more highly concentrated and accelerated process in evolution than that which occurred at any subsequent period of the earth's history.

The history of the Porifera and higher Protozoa suggests also that the evolution of the Metazoa may have occurred more rapidly than we can now calculate. One of the great errors of the present day is the assumption that such changes and transitions occurred slowly and gradually; and it is evident that this assumption is based almost wholly upon investigation of the more highly specialized animals, in which the capacity for change may be reasonably considered as very much less than in their more generalized and embryonic ancestral forms.

XXIII.-Preliminary Communication on some Investigations upon the Histological Structure of the Central Nervous System in the Ascidia and in Myxine glutinosa. By FridtJof Nansen *.

IT is proposed in the following pages to give only a mere

* Translated by W. S. Dallas, F.L.S., from the 'Bergers Museums Aarsberetning for 1885,' pp. 55-78. 
preliminary report upon some of the results at which $I$ have arrived in the course of the investigations which I undertook last summer (June and July 1885) in Alverströmmen (near Bergen), at the expense of Joachim Friele's legacy, which by the liberality of the Direction of the Museum was granted to G. A. Hansen and myself. I will expressly call attention to the fact that these investigations are not completed, and that therefore, for the present, it will not be advisable to go more in detail into the subject; but as I believe that some of these results may be of general interest, I venture in the meanwhile to publish them in their imperfect form.

The results at which I arrived in my investigations upon the histological structure of the nervous system of the Myzostomata, and which Ihave described in my memoir upon the structure of this group of animals *, stood in so remarkable a manner in agreement with many of the characters which Prof. C. Golgi (of Pavia) has described in the central nervous system (brain and spinal cord) of man, that it became a matter of much interest to me to have investigated some groups of animals lying between these widely separated forms. With this object in view I turned to the group of Ascidia (so much a subject of dispute from a systematic point of view), with the nervous system of which I had previously occupied myself, and in which I expected to be able to find something of interest. In the next place I wished to examine some low vertebrate animal, and selected the hag-fish (Myxine glutinosa), of which I could obtain abundant material.

The points which it was of essential interest to have investigated were as follows:-

1. Does the fibrillar mass of the central nervous system consist of two constituents $†-a$, a fibrillar net, or, as I will call it for the sake of clearness, a fibrillar web, consisting of fine fibrillæ, which in their crooked and intricate course cross one another in every direction; and $b$, coarser percurrent "nerve-cylinders," which either traverse the whole fibrillar mass of the central nervous system, and thus connect its different parts with each other, or run out into peripheral nerves?

2. Have all the nerve-cells (whether unipolar or multipolar) only one real nervous process (" prolongation nerveux ou fonctionnel "), and can the nerve-cells be divided into the following two types :- $a$, first type, of which the nervous pro-

* “Bidrag til Myzostomernes Anatomi og Histologi,” Bergens Museum, 1886.

$\dagger$ As described in the above-cited work on Myzostoma, p. 33. 
cesses, after giving off small side-branches, pass directly into a peripheral nerve and form a peripheral cylinder; $b$, second type, in which the nervous processes divide up into small branches, which lose themselves in and contribute to form the fibrillar web?

3. Do the nerve-cylinders in the peripheral nerves consist of two kinds :- $a$, in the first place, of nerve-cylinders, which originate directly from nerve-cells and constitute continuations of the nervous processes of the latter; $b$, in the second place, of nerve-cylinders, which originate from the fibrillar net, and are produced by a union of many small branches?

4. Do certain nerve-cells send out their nervous processes directly into the peripheral nerves without their passing through the fibrillar mass of the central nervous system, and can nerve-cells occur in the course of the voluntary nerves?

5 . What is the case of the primitive fibrillæ described by Hermann *, Hans Schultze $\dagger$, and others? are these a really existent nerve-element, and how are they to be regarded?

6 . In what relation do the nerve-elements of the Invertebrate animal stand to those of the Vertebrate? are the nerve-tubes ("tubes nerveux"), or, as I have called them, "nervecylinders," of the Invertebrate homologous with the "axiscylinders" of the Vertebrate animal?

These are questions of no small importance which still wait for a satisfactory scientific solution. They are, however, questions the answers to which, at all events in part, still lie upon the limits of the range of modern microscopy, and, especially in what relates to the nervous system of Invertebrata, we have such great technical difficulties to contend with that we can only hope that for some time to come we shall probably have to content ourselves more or less with assumptions. The point is to find new and certain methods of investigation quite different from those which have hitherto been generally adopted.

My investigations to the present time can therefore make no claim to give a satisfactory solution of these questions; they must be regarded only as a tentative effort to climb over a hill, which certainly is not insurmountable, but which it will need severe labour to get right over.

\section{Central Nervous System of the Ascidia.}

The histological structure of the nervous system of the Ascidia has remained until quite recently as good as uninves-

* 'Das Centralnervensystem von Hirudo medicinalis:' Munich, 1875 (Prize essay).

† "Die fibrilläre Structur der Nervenelemente bei Wirbellosen," in Arch. f. mikr. Anat. Bd. xvi. 1879. 
tigated; it was only within the last few years that some light was thrown upon it especially by the writings of Prof. E. van Beneden and Dr. C. Julin *, but it still remains very backward. The central nervous system consists of the brain, situated between the apertures of the mouth and the cloaca, from the posterior end of which there issues the dorsal ganglionic cord ("cordon ganglionnaire visceral ou dorsal ") described by Van Beneden and Julin, which extends backwards past the cloacal aperture until it disappears in the neighbourhood of the liver $\dagger$.

Hitherto it has been the brain that has particularly interested me. With it I have tried many different modes of treatment, but none has as yet given satisfactory results; of course, I have employed all the ordinary methods with osmic acid, chromic acid, bichromate of potash, bichloride of mercury, \&c., as also staining with carmine, hæmatoxyline, aniline colours, \&c., and I have further made trial of Golgi's method (with bichromate of potash and nitrate of silver), but without obtaining the desired results, so that it will now be my endeavour to find out new methods. Golgi, in his method, has found one which, as regards the Mammalia and the higher Vertebrata, furnishes images of such striking distinctness that we cannot wish for better ; the point now is to discover a method which may give similar results in the case of the lower animals, and only then can we give any more satisfactory answers to the questions above formulated.

* C. Julin, "Rech. s. l'Organisation des Ascidies simples," in Arch. de Biol. tome ii. (1881), pp. 59-126; E. van Beneden et C. Julin, "Le système nerveux central des Ascidies adultes," in Arch. de Biol. tome v. (1884).

$\dagger$ My investigations of this cord have as yet been quite superficial; but it would appear as if it may have a somewhat different structure in the different species. In the species which I have especially examined (Phallusia venosa, P. mentula, P. obliqua, Ascidia scabra, Corella parallelogramma) it has only a small development: the ganglion-cells generally are slender, elongated (bipolar), and closely packed together; it is but seldom that they are of the size of those found by Van Beneden and Julin in the species of Molgula (M. ampulloides) investigated by them; further, it appears that their arrangement and position may differ considerably from what the above-mentioned naturalists found in Molgula. It was but rarely that one could perceive any tendency in the cells to an arrangement about a common central axis, towards which their processes were directed; on the other hand, in several species, at any rate, I have found two fibrillar cords running one on each side of the principal mass of the cells, by which means the cells therefore come to occupy the middle of the ganglionic cord, a position which, regarded superficially, might remind one of the position of the cells in the spinal cord of the Vertebrata. I believe that I have several times seen nerves going off from the ganglionic cord. 
Here I shall only report what I think I have observed with regard to the minute structure of the brain of the Ascidia; with respect to the more topographical description I will refer to the memoirs by C. Julin and E. van Beneden, already cited.

1. I find the fibrillar central mass to consist of two constituents, just as already described in the Myzostomes ( $l . c$. p. 33). In the first place, a fibrillar web. This web is diffused throughout the whole mass, and gives it, in section, that spongy appearance which led Leydig to imagine that the fibrillar mass, or, as he called it, the "Punktsubstanz," has a spongy structure. It consists, however, in my opinion, of fine fibrillæ, which are most intimately intermixed, so that they appear to be interwoven with each other, but, at any rate, in general, without anastomosing with each other in the manner recently described in the case of the Rhipidoglossa by Dr. Béla Haller*. It is in the settlement of these difficult points in the lower animals that we are specially brought to feel how far our modes of investigation are still from being sufficient. I have certainly seen nearly the same images that Dr. Haller describes, and when his drawings are compared with mine this will certainly be the impression; but I am afraid that what Dr. Haller describes and figures as a fibrillar, anastomosing network is in reality nothing of the kind, but is connective substance, or, as Leydig calls it, "spongioplasma," which, in my opinion $\dagger$, encloses and isolates the individual fibrillæ, and does not, as Leydig thinks, extend as a spongy tissue throughout the whole mass. If we compare sections of the fibrillar central substance with transverse sections of peripheral nerves it must certainly be confessed that in appearance these resemble each other; in both we shall see a distinct reticular web, consisting apparently of anastomosing fibrillæ; the only difference is that in the divided nerve the meshes are considerably coarser. We know, however, that here an isolation really occurs, and that every mesh is in reality a divided tube of spongioplasma, which encloses a hyaloplasmatic cord, a "nerve-cylinder," which in its turn either originates from or at any rate (with but few exceptions) traverses the fibrillar central substance. If it is connected with that substance, I cannot see but that to a considerable extent it testifies in favour of the view that the reticular web which one sees by the ordinary methods of preparation is in reality connective substance or "spongioplasma," which sur-

* For his work see further on, p. 224.

$\dagger$ Just as I have already stated in the description of the nervous system of the Myzostomes (l. c.). 
rounds the true nervous "hyaloplasmatic" fibrilla, which are generally nearly uncoloured.

Besides the fibrillar web we also find in the fibrillar mass percurrent nerve-cylinders, which usually appear to start from ganglion-cells and run to peripheral nerves. These percurrent nerve-cylinders are, however, difficult to observe; they are certainly of greater calibre, but they generally become stained by the same process as the fibrillar network, and as their course is not always the same it is difficult to trace them far. For shorter distances, however, they may be traced, and there can be no doubt of their actual presence; we can even in some places perceive a tendency to the formation of bundles or larger cords of fibrils. Percurrent nervecylinders, the exclusive destination of which would be the establishment of a general communication, I have not been able to demonstrate with certainty in the brain, although there is every probability of their existence here also. In the dorsal ganglionic cord, however, I have unmistakably seen such.

The nerve-cells in the brain of the Ascidia are of the most different appearance and size. Those which especially strike the eye in a section through an Ascidian brain are those of the outer layer which surrounds the central fibrillar mass. The cells of this layer are divided by Van Beneden and Julin* into three categories. The smallest occur furthest in, in immediate contact with the fibrillar mass; the largest occur exclusively in the periphery of the organ, and those of medium size between these two. They say: "Tandis que les petites et les cellules ganglionnaires moyennes constituent autour de la masse ponctuée une couche continue nettement délimitée, les grandes cellules ne se rencontrent qu'en certains points ....."

2. I find that this description applies pretty well, at least in its main features, to the species examined by me. We certainly find cells of all possible sizes from the smallest to the largest; but we shall always see that these last are generally situated outermost, while the smallest for the most part lie innermost. Among these cells I have found both multipolar and unipolar forms; but the latter are beyond comparison the most general; the large cells especially appear to be principally unipolar. Among all these cells of such different sizes in this outer layer I have found both forms of nervous processes represented; there are cells with processes which pass directly to form peripheral nerve-cylinders, and others with processes which divide up and lose themselves in ${ }^{*}$ Loc. cit. p. 332. 
the fibrillar web. Hitherto I have been unable to find any constant difference in this respect between cells of different sizes.

Besides these cells in the peripheral layer surrounding the central fibrillar mass there is also another form of ganglioncell, which occurs in the fibrillar mass itself. These are small multipolar cells with an ovate nucleus. Van Beneden and Julin have observed these cell-nuclei in sections; they have also stated that they were possibly of nervous nature, saying * : "Il s'agit probablement là de petites cellules nerveuses allongées dans le sens antéro-postérieur, unipolaires ou bipolaires, et disséminées dans la substance fibrillaire." I have examined these cells both in sections and by the aid of maceration; the latter method especially gave me the best results; and $I$ find that there can be no doubt as to their truly nervous nature. They are small multipolar cells, generally at least tripolar, the form of which reminds us in no small degree of the three-cornered form of small cells in the brain of the Vertebrata; the processes which originate from their most pointed end are the nervous processes, and these I have often been able to trace very far, in macerated preparations I have even succeeded in isolating them for a long distance ; but I have nowhere found any ramification. In sections I have often seen them directed towards the origin of the peripheral nerves; and I therefore regard it as in the highest degree probable that these small tripolar or multipolar cells belong, at all events for the most part, to the type of nervecells, the nervous prolongations of which go directly to form peripheral nerve-cylinders. In the other processes of these cells, which may therefore be said to correspond to "Deiler's protoplasma-processes," I have frequently been able to see ramifications.

In conclusion, with regard to this question of the form and the processes of the nerve-cells I will remark that it has appeared to me on two occasions that I could see true processes from cell-nuclei, prolongations which united themselves again with other smaller cells. This therefore would be something comparable with what Dr. Béla Haller has described in the Rhipidoglossa, in which he thinks he has found numerous nuclear processes of the most different forms. Of the actual nuclear nature of these processes, however, I feel by no means perfectly convinced; I am afraid that the images of such a nature which I have hitherto had before me in the Ascidia may be due to an optical illusion, and

* Loc. cit. p. 334. 
remain for the present somewhat doubtful as to their actual presence.

If I now summarize my results with regard to the nervecells and their processes in the brain of the Ascidia, they prove to be in the fullest agreement with the results at which I arrived in the Myzostomes, and in their principal features also with results obtained by Dr. Béla Haller in the Rhipidoglossa, only I must point out that in the Ascidia I have not succeeded in demonstrating undoubted anastomoses between the processes of the different cells, such as Haller describes in the Rhipidoglossa.

3. As regards the origin of the nerve-cylinders, as my investigations hitherto have not been specially directed to this point, only this much can be said about it, that from what I have hitherto seen there appears here also to be an agreement with my earlier results in the Myzostomes. There would consequently exist two forms, one originating directly from nerve-cells, and one originating from the fibrillar webtherefore two forms just such as Golgi has demonstrated in man.

4. With respect to the fourth point, it is not difficult to observe nerve-cells situated near the origin of the peripheral nerves and emitting their processes directly into the peripheral nerves without first passing through the fibrillar central mass. I have also found, in the peripheral nerves even at a distance from the brain, nerve-cells which sent their nervous processes in a peripheral direction and not inwards towards the central organ. This is therefore a condition which stands in the most perfect agreement with the condition in the Myzostomes, and does not agree with Vignal's * (and Ranvier's) assumption of the non-existence of such cells in the voluntary nervous system. Whether side-branches are not given off from the nervous prolongations of these cells, by which they are connected with the central fibrillar web, I have not yet been able to ascertain, although it certainly appears to me to be probable.

As regards the sixth and seventh points, I will reserve my reference to them until later on, when it will be possible to go into the matter more in detail; for, in the first place, the investigations in this direction are still far from complete, and, secondly, a hasty description of them would lead only too easily to misconceptions.

Summing up the main points in the above superficial description of the Ascidian brain and comparing it with my

* Vignal, "Rech. histol. sur les centres nerveux de quelques invertébrés," in Arch. de Zool. Expér. sér. 2, tome i. (1883). 
former description of the nervous system of the Myzostomes, it will be seen that we have here obtained a good confirmation of the results furnished by the latter. It may now be of interest to investigate how the conditions stand in the lowest forms of Vertebrata. Of these I have as yet properly investigated only the hag (Myxine glutinosa).

\section{The Central Nervous System in the Hag (Myxine glutinosa).}

Of this interesting animal it is easy, at Alverströmmen, to obtain abundant material; but the time was too short to allow any thorough investigation to be undertaken; during the coming summer I hope to have an opportunity of doing this, and it may even be expected that with new fresh material I may try new and better modes of investigation. Here therefore I will only express myself with extreme brevity.

So far as I know, no one has recently paid particular attention to the histological structure of the central nervous system of Myxine; on the other hand, something is known of the histology of the nervous system in the genus Petromyzon. In Dr. Ahlborn's memoir, "Untersuchungen über das Gehirn der Petromyzonten" *, there is a detailed description of the topography of the brain in Petromyzon, as also a portion of the histology of the brain and spinal cord ; there will likewise be found in it a list of the earlier literature of the subject. Our histological knowledge of Petromyzon also is unfortunately rather defective, and there still remains much to be made out.

It appears that the structure of the nervous system in Myxine and Petromyzon, notwithstanding many differences, is on the whole tolerably accordant. It is especially to the spinal cord that I have hitherto directed my attention.

As is known, the spinal cord in Myxine, as in Petromyzon, has that flat band-like form which at once catches the eye in transverse sections. On the ventral surface there is a considerable longitudinal depression or groove, a kind of sulcus longitudinalis ventralis, if one may call it so; on the dorsal surface, on the contrary, there is no trace indicative of such a groove.

The space between the central canal and the ventral longitudinal furrow is occupied by a considerable markedly fibrillar mass of connective tissue, in which the fibrillæ from the two sides cross one another, and, at any rate for the greater part, are in connexion with the pia mater on both sides of the longitudinal furrow; a similar mass has also been described

* Zeitschr. für wiss. Zool. Bd. xxxix. (1883), pp. 191-294.

Ann. \& Mag. N. Hist. Ser. 5. Vol. xviii. 
by Ahlborn in Petromyzon. The fibrillæ in this mass are partly processes from the epithelial cells of the central canal, partly processes from cells situated outside of these in the grey substance (see further on). On the dorsal side a thin septum of fibrillar tissue extends from the central canal to the pia mater. The fibrillæ in this septum consist, at any rate for the most part, of processes coming from the epithelial cells of the canal and from circumjacent cells. By these two septa or fibrillar masses the spinal cord is therefore divided into two lateral symmetrical parts.

The Grey Substance.-There is a considerable difference between the grey and the white substance. The former, in transverse section, has a broad and depressed form, corresponding to the external form of the spinal cord. A distinction of the anterior and posterior form is difficult to observe, and its actual existence can only be made out by careful investigation. In Petromyzon Ahlborn was unable to demonstrate the posterior horn. In Myxine I have found this possible, having been able, by means of different methods of staining, to trace the course of a great part of the fibrillæ which run to the posterior nerve-rods directly from the vicinity of the grey substance (see further on); it appears distinctly that the two small "horns," which Ahlborn has also observed in Petromyzon, and which are situated on each side close by the above-named septum, which goes off dorsally from the central canal, in reality correspond to a part of the posterior horn in the higher Vertebrata, inasmuch as the greater part of the fibrillæ passing to the posterior rods can always be seen to come from the white substance in the vicinity of these small horns, or the portions of the grey substance lying nearest on the outer side; exceptionally I have been able to trace fibrillæ quite from the small horns (probably originating directly from cells here) and quite to the posterior rods. In the anterior nerve-rods I have frequently been able to trace the fibrillæ quite from the ventral outer parts of the grey substance; but how much of the outer parts is to be referred to the anterior horn I am still unable to ascertain.

Just as in Petromyzon, the ganglion-cells in the grey substance may be of extremely different sizes. There are some which especially catch the eye by their remarkable magnitude; these are only few in number, and are regularly situated in the outer, more lateral part of the grey substance, and therefore essentially in the part which must chiefly be referred to the anterior horn. These cells, with their processes, generally stain very strongly, especially with various aniline colours (acid fuchsine, nigrosine, safranine, \&c.). The smaller cells 
are somewhat variable in size; they are distributed through the whole of the grey substance, occurring most numerously in its middle parts, the parts therefore which should be regarded as belonging to the posterior horn. These cells, with their processes, are generally less strongly coloured by staining fluids. To regard these different colour-reactions as indicating a constant difference from a physiological point of view, such as Bellonci * thinks he has demonstrated, and such as Ahlborn seems likewise inclined to assume in Petromyzon, appears to me to be still doubtful. It is certainly the case that the smaller cells which stain less strongly occur particularly in the middle portions pertaining to the dorsal nerve-rods, and therefore may be assumed to be especially sensitive; but I have also observed in the outer ventral parts similar cells which emitted their nerve-processes directly to the ventral nerve-rods, and as to the motor nature of which it seems to me therefore, in accordance with Golgi's work, there can be but little doubt ; it must, however, be admitted that the cells here situated appear generally to have a tendency to become more strongly coloured than those placed in the middle part.

As regards the form of the ganglion-cells, they appear to be always multipolar, with pretty strongly branched protoplasmatic processes. I have frequently been able to trace these, with their ramifications, into the white substance; but whether they extend quite to the periphery of the spinal cord I have not hitherto been able to make out, although I believe I have often observed it. This is a point which it may be of interest, in connexion with the significance of these processes, to have cleared up; if the function of these processes be, as Golgi thinks and as seems to me probable, exclusively nutritive, we have here in Myxine the remarkable fact that no vascular system is present in the spinal cord.

I have only been able partially to trace the nervous processes; the processes especially which run to the ventral nerverods, and pass directly over to form the axis-cylinder, have been the easiest to observe ; these processes therefore appear perfectly to agree with what Golgi has described, and, at any rate, to belong chiefly to "the anterior horn" and the ventral nerve-rods; nevertheless I believe that, as above stated, I have quite exceptionally observed similar ones in the posterior horn running to the dorsal nerve-rods. As a rule I have

* "Ricerche intorno all' intima tessitura del cervello dei Teleostei," in Atti d. R. Accad. d. Lincei, A. 276, 1878 (1879); and "Ricerche comparativa sui centri nervosi dei Vertebrati," in Atti d. R. Accad. d. Lincei, A. 277,1879 (1880). 
found it impossible to trace the nerve-processes in the posterior horn (therefore in the middle part of the grey substance)just as the fibrillæ running to the dorsal nerve-rods can only be traced for longer or shorter distances, and only very rarely quite to the grey substance. This appears also to show an agreement with Golgi's description of the human spinal cord, and I must assume that the nerve-processes in this middle part of the grey substance (the posterior horn) at any rate for the most part divide up into small branches and lose themselves in the fibrillar web, from which again most of the fibrillæ in the dorsal nerve-rods originate; the correctness of this view, however, remains to be proved by more certain methods of investigation.

Besides the above-mentioned cells, a second kind of cell occurs in the grey substance. Similar cells have also been described by Ahlborn in Petromyzon. They appear, as that author also admits, not to be of nervous nature, but rather to belong to the connective substances; they are chiefly situated around the central canal, and perfectly agree in appearance and form with the epithelial cells in the epithelium surrounding the central canal. Each of these epithelial cells has a very long process, which is very easy to trace by suitable methods of treatment; I have even frequently been able to trace them quite to the periphery of the spinal cord; probably, indeed, this is the case with all these processes, so that they form connective fibrils radiating to the periphery. This appears indeed to be the general condition in the Vertebrata. Prof. Golgi long since found a similar condition in the fowl's embryo; 1 have myself seen his preparations, in which it was to be observed remarkably distinctly (he has, however, as yet published nothing on the subject). I have myself also recognized it in the spinal cord of the tench (Tinca vulgaris) which had been treated in accordance with Golgi's method. The cells situated outside of the central canal in Myxine have similar processes, and it is probable that these comport themselves in the same way. As previously stated, the connective tissue or supporting substance existing between the central canal and the ventral longitudinal furrow seems to consist of similar intercrossing fibrillæ. As will be stated further on, there occur everywhere in the white substance similar fibrillæ radiating from the grey substance to the periphery; it is also possible that all these come from similar cells situated in the grey substance, and that the whole primarily in the embryo originate from the epithelial cells surrounding the central canal. The White Substance.-The general divisions of the white 
substance into the funiculus dorsalis and funiculus ventralis and the funiculus lateralis, which Ahlborn also has employed in Petromyzon, I do not find to be really quite characteristic ; but as they present several advantages for descriptive purposes, I will nevertheless retain them. The above-mentioned radial fibrillæ occur in the whole of the white substance, but they appear in the greatest number in its dorsal part, in the funiculus dorsalis and the dorsal parts of the funiculus lateralis, where their radial arrangement is also most easily observed. A grey granular mass, which Ahlborn * describes in Petromyzon as existing between the pia mater and the white substance, I have been absolutely unable to observe in Myxine; on the contrary, I have always been able distinctly to demonstrate the connexion of the radial fibres with the pia mater; and I assume that the same must also be the case in Petromyzon and that the grey mass which Ahlborn saw in his osmic-acid preparations was probably an artificial product, as he himself appears also to suppose. Between the radial fibres a network of fine fibrillæ is interwoven, which, in great part at any rate, must be regarded as of the same nature as the former, and therefore as belonging to the connective substances. Besides these parts belonging to the connective substances, we have also in the white substance the true nervous constituents. Of these what especially catch the eye in a transverse section of a spinal cord are the coarse longitudinal fibres, which occur especially in the ventral part, in the funiculus ventralis, and partly in the funiculus lateralis. These, which are the socalled "Müllerian fibres," were first described by Johannes Müller; there is, however, no other difference than size between them and the finer longitudinal fibres, and all possible transition-stages occur, from the very coarsest to the very finest. The coarsest longitudinal fibres are situated, together with others of smaller calibre also, in the funiculus ventralis on both sides of the ventral longitudinal furrow; they appear to be present in greater number than in Petromyzon, in which Ahlborn notes about eight coarser fibres ; to give any definite number seems to me, however, to be quite arbitrary, seeing that, as already stated, there are all possible transitions, and therefore it is impossible to lay down any limits. Numerous longitudinal fibres likewise occur in the funiculus lateralis, especially in its more ventral parts; there are, however, only a few very coarse ones, and the calibre of the fibres diminishes 
towards the dorsal surface *. In the funiculus dorsalis $\mathrm{I}$ have been unable to discover any longitudinal fibres, nor could Ahlborn do so in Petromyzon. This author, however, notes the possibility that the granules observed by him in the network may be divided fine longitudinal fibres; but this seems not very probable. I doubt the real existence of longitudinal fibres in this part of the spinal cord, and regard the nervous parts of the funiculus dorsalis as consisting exclusively of what I have previously called the fibrillar web, Golgi's "entrelacement nerveux diffus." This fibrillar web is also found distributed in the other parts of the white substance among the longitudinal fibres in both the funiculus lateralis and the funiculus ventralis; it is, however, most predominant in the more dorsal parts of the spinal cord, therefore, as stated, in the funiculus dorsalis and the funiculus lateralis, especially in the dorsal parts of the latter.

The Nerve-rods.-As already stated, I have often succeeded in tracing the fibrillæ passing to the ventral rods quite from the grey substance, nay, even from their origin from ganglioncells; but I have found this possible only exceptionally with the dorsal nerve-rods. As regards a portion of the fibrillæ (those running most dorsally) at any rate $I$ have been able to trace them for a tolerably long distance from their entrance into the dorsal nerve-rods; but there has always been a small space between them and the grey substance, in which they could no longer be traced, while in this neighbourbood they were also more diffused and divided up than towards the nerverods. From this I conclude, as already mentioned, that these nerve-fibres belong for the most part to the form which originates from the fibrillar web, while the fibrillæ running to the ventral nerve-rods principally originate from ganglioncells. As regards their size, the dorsal nerve-rods seem to be considerably larger and to contain a good many more fibrillæ than the ventral nerve-rods, just as the field from which the fibrillæ for the dorsal rods originate is considerably larger than that from which the ventral fibrillæ spring.

* In transverse sections the longitudinal fibres always appear considerably wrinkled, so that a vacant space is formed around each of them, which, as Ahlborn has also noted in Petromyzon, indicates the original form of the fibres. In transverse sections the divided longitudinal fibre generally appears as a strongly-coloured mass upon the wall of this cavity. The elliptical transverse section of this cavity I have been unable to observe definitely as Ahlborn describes it; it apptars to me generally to be nearly round; there are certainly many differences, but these I regard generally as artificially produced. 
The Brain in Myxine I have as yet investigated only quite superficially, and therefore I will not at present enter upon any particular description of it. This much, however, may be said-the size of the nerve-cells appears to vary still more than in the spinal cord. There are very large cells which occur only in small numbers, and at the same time there are extremely small cells, which appear in very considerable numbers, especially in the anterior parts of the brain; in the cerebrum they are diffused quite uniformly throughout the whole mass. The large cells generally stain more strongly than the smaller ones; but this can be of no significance from a physiological point of view, as among both the larger and the smaller cells there seem to be cells of both the types described by Golgi, namely with processes which go directly to form peripheral "nerve-fibrillæ," and with processes which divide up in the fibrillar web, as is not difficult to demonstrate. In many preparations I believe quite definitely that I can see anastomoses between the protoplasmatic processes of different large nerve-cells; in spite of the most careful examination with homogeneous immersion-lenses (Zeiss $\frac{1}{18}$ ) I was unable to come to any other conclusion than that such anastomoses were present; nevertheless I will say nothing decided upon this point, and will still treat it as doubtful, until it is possible to make a more thorough examination of many preparations.

\section{Conclusion.}

If, after giving this certainly very superficial description of investigations upon the central nervous system in the Ascidia and Myxine, we bring together in conclusion the results which may be regarded as arrived at, and compare them with the seven different questions or propositions which we commenced by formulating, it must certainly be admitted that, omitting the last question, which has not been particularly treated of here, the others appear to have been pretty thoroughly confirmed, and the conditions found are in agreement both with what I have previously found in the Myzostomes and with what Prof. Golgi has ascertained in man and in the higher Vertebrata (Mammalia); it might therefore from this even now appear to be a probable supposition that these conditions occur throughout the whole animal kingdom, in which generally a more developed nervous system exists.

In passing I will call attention to an agreement between the above description of the spinal cord of Myxine and the 
description previously given of the ventral cord of Myzostoma, an agreement to which I certainly will not ascribe great importance, but which has nevertheless struck me as remarkable and as, at any rate to a certain extent, indicative of a homology between the spinal cord and the ventral cord. As we have seen above, the nerve-fibres traversing the spinal cord longitudinally are essentially situated towards the ventral surface, while the fibrillar web appears especially on the dorsal side. In the ventral cord of Myzostoma, on the contrary, the fibrillæ which run longitudinally were situated on the dorsal side, while the mass of the fibrillar web constituted the ventral part of the ventral cord. Here also, especially, were situated the cells, the nervous processes of which divide up into the fibrillar web; while the cells which send their processes directly into the peripheral nerves belong essentially to the dorsal surface, therefore altogether exactly the opposite of what we found in Myxine. However, if we regard the ventral cord and the spinal cord as homologous, we must also imagine the ventral cord as turned with its dorsal surface downwards, that is to say the dorsal surface in Myzostoma corresponds to the ventral surface in Myxine, and vice versâ; and if we consider the above-mentioned conditions we shall find the most beautiful agreements. According to Dr. Haller's description it appears that in this respect a similar condition to that here mentioned in the Myzostomes occurs in the Rhipidoglossa. As already said, I will not from our present standpoint ascribe any greater significance to this; but it nevertheless seems to me to be possible that, when more thoroughly investigated, it may show itself to have a deeper foundation.

After these investigations were undertaken last summer at Alverströmmen, and at the same time that my memoir on the structure of the Myzostomes was printed in the winter, the very remarkable memoir by Dr. Béla Haller on the structure of the central nervous system in the Rhipidoglossa * appeared in the 'Morphologisches Jahrbuch,' in which that author has arrived at results which in many respects stand in striking agreement with those above detailed and with the results obtained in the case of the Myzostomes. This is certainly not the place to go in detail into this memoir; but I will state in a few words the points in which, from my investigations, I cannot perfectly agree with 1 r. Haller.

He has, like myself, two forms of peripheral nerve-fibrillæ, some which originate directly from ganglion-cells and others

* "Untersuchungen über marine Rhipidoglossen," in Morphol. Jahrb. Bd. ii. 1885, pp. $321-436$. 
which originate from the "fibrillar net;" in the next place he has found two types of nerve-cells (such as Gerlach had previously supposed to occur in the spinal cord of the Vertebrata *), namely a type which sends its nervous process directly to a peripheral nerve, and a second type, the nervous processes or, at any rate, "processes" of which divide up in the fibrillar net $\dagger$. The ramifications of this latter kind of processes, however, in Haller's opinion, form an actual reticular net; therefore they anastomose and form real meshes, which, as already pointed out, is in opposition to my conception of them. Then Dr. Haller, like Gerlach, thinks that the fibrillar net (or web, as I believe) is also formed by "nonnervous processes" of the ganglion-cells, and therefore by Deiter's " protoplasmatic processes," which, according to what has been above stated, is not in agreement with the results at which I have hitherto arrived. Dr. Haller did not know Prof. Golgi's very important investigations; according to these it seems to me to be made out that, at any rate in the higher Vertebrata, the fibrillar web is formed by the nervous processes, of which there are never more than one to each cell, and not by the protoplasmatic processes, which do not serve to connect the different ganglion-cells, but, in accordance with Golgi's opinion, exclusively have to do with the nutrition of the cells. Anastomoses or unions between the different ganglion-cells by their processes, which Haller describes as the regular condition in the Rhipidoglossa, I have been unable to demonstrate with certainty in the groups of animals investigated by me, at any rate as the rule. As regards the numerous nuclear processes described by him, I have been unable, as already stated, to convince myself positively of their existence from my preparations, although in many cases it has seemed to me probable.

'I'hese are the most important points in which, from a rapid perusal of Dr. Haller's important memoir, I do not think that I can agree with him; on the whole, however, his and my results may be said to confirm each other to a very considerable extent, and possibly we have thus advanced to a somewhat more solid basis for investigations upon this difficult subject. In a letter Dr. Haller has moreover informed me that he has met with the conditions described by him not only in the Mollusca, but also in the Chætopoda $\ddagger$ and in the

* J. Gerlach, "Von dem Rückenmark," in Strickker's 'Handbuch der Lehre von den Geweben' (Leipzig, 1872), p. 684.

† This kind of cells, however, Gerlach called " cells without nervous processes," therefore only with protoplasmatic processes.

$\ddagger$ I have also, both in Polychæta and Oligochæta, met with conditions corresponding to those which I have described in the Myzostomes. 
spinal cord of various Vertebrata, and he thinks that J. Gerlach's older important discoveries are in this way confirmed and extended, and that they may be admitted for all bilateral animals. Although I cannot quite agree with this as regards Gerlach's descriptions, it may nevertheless be assumed that here all turns upon the condition which, as I have above indicated, at any rate in its main features, occurs throughout the whole animal kingdom, in which, generally, a more developed nervous system is present. To discuss this matter in its minute details and to clear up the many doubtful points will be an affair of the future.

XXIV.-On the Genus Hindia and its Species. By Prof. P. Martin Duncan, M.B. (Lond.), F.R.S., \&c.

DR. H. RAUFF has been so kind as to send me a copy of his paper " Ueber die Gattung Hindia, Dunc." (Separat-Abdruck aus den Sitzungsber. der niederrh. Gesellschaft zu Bonn, Mai 10, 1886). He has confirmed the truth of the diagnosis which I gave of the very beautiful species, and he admits the genus as correct. Dr. Rauff does more than this; he utterly demolishes Prof. Steinmann, who with "grosser Entschiedenheit "wrote that the Hindia was not a sponge and had neither oscule, canals, nor spicules! It is very pleasant to have one's battles fought by an able foreign naturalist, and Dr. Rauff has my sincere thanks.

The description of Hindia as a genus and of its species, H. sphceroidalis, was published in the Ann. \& Mag. Nat. Hist. ser. 5, vol. iv. 1879, p. 84, pl. ix. It will be noticed (p. 91) that there are canals and that the spicules are tetraclade. The figures given were drawn from nature by A. S. Foord, and figs. 1 and $2 b, e$, give exact representations of the tetraclade elements of the canals, which are also in part represented in fig. 4. Prof. Steinmann says that the canals and spicules do not exist, and it follows that if he is correct the author of the paper was romancing and the able artist was drawing from his imagination. The most charitable proceeding is to suppose that the professor has not seen the paper on Hindia and has not had the opportunity of examining the type, part of which is at Munich. It is perfectly proved by Dr. Rauff that the morphology of Hindia was correctly described, and it is not therefore necessary to pursue the 


\section{$2 \mathrm{BHL}$ Biodiversity Heritage Library}

Nansen, Fridtjof. 1886. "XXIII.-Preliminary communication on some investigations upon the histological structure of the central nervous system in the Ascidia and in Myxine glutinosa." The Annals and magazine of natural history; zoology, botany, and geology 18, 209-226. https://doi.org/10.1080/00222938609459961.

View This Item Online: https://www.biodiversitylibrary.org/item/53334 DOI: https://doi.org/10.1080/00222938609459961

Permalink: https://www.biodiversitylibrary.org/partpdf/51290

\section{Holding Institution}

Smithsonian Libraries

\section{Sponsored by}

Smithsonian

\section{Copyright \& Reuse}

Copyright Status: Public domain. The BHL considers that this work is no longer under copyright protection.

This document was created from content at the Biodiversity Heritage Library, the world's largest open access digital library for biodiversity literature and archives. Visit BHL at https://www.biodiversitylibrary.org. 